\title{
Erratum to: The implications of phasing out conventional nutrient supply in organic agriculture: Denmark as a case
}

\author{
Myles Oelofse • Lars Stoumann Jensen • Jakob Magid
}

Published online: 21 November 2015

(C) Springer Science+Business Media Dordrecht 2015

\section{Erratum to: Org. Agr. (2013) 3:41-55 \\ DOI 10.1007/s13165-013-0045-Z}

The published online paper unfortunately contained an error in nutrient amounts for industrial sector organic waste in Table 3. We apologise for any inconvenience this error may cause. The updated table is provided below

Table 3 Theoretical nutrient supply potential by non-farm organic waste type in Denmark

\begin{tabular}{|c|c|c|c|c|}
\hline & $\mathrm{DM}(\mathrm{t})$ & $N(t)$ & $P(t)$ & $\mathrm{K}(\mathrm{t})$ \\
\hline Household source segregated organic waste (currently recycled) ${ }^{\mathrm{a}}$ & 14,865 & 282 & 34 & 189 \\
\hline Household waste, organic fraction estimate (currently incinerated) ${ }^{a}$ & 228,800 & 4347 & 526 & 2906 \\
\hline Garden and park waste (private and public) & 409,635 & 2222 & 394 & 3892 \\
\hline Service sector organic waste ${ }^{\mathrm{a}}$ & 9756 & 185 & 22 & 124 \\
\hline Industrial sector organic waste $^{\mathrm{a}}$ & 35,495 & 674 & 82 & 451 \\
\hline Sewage sludge & 132,600 & 6312 & 4150 & 716 \\
\hline Total $(\mathrm{t})$ & 831,151 & 14,023 & 5209 & 8277 \\
\hline Supply to organic agriculture $(\mathrm{kg} / \mathrm{ha})^{\mathrm{b}}$ & 4790 & 81 & 30 & 48 \\
\hline
\end{tabular}

Sources: (1) Waste quantities: Danish Ministry of the Environment 2011; Danish Ministry of the Environment 2009; Pers comm. Petersen (2011); (2) nutrient contents: Boldrin (2009); Boldrin and Christensen (2010); Boldrin et al. (2011); Danish Ministry of the Environment 2009

${ }^{\text {a }}$ Based on the nutrient content of the vegetable food waste fraction of household waste

${ }^{\mathrm{b}}$ Based on a theoretical distribution of total nutrients from organic waste streams to all organic land in Denmark (173,517 ha)

The online version of the original article can be found at http://dx. doi.org/10.1007/s13165-013-0045-z.

M. Oelofse $(\bowtie) \cdot$ L. S. Jensen $\cdot$ J. Magid

Department of Plant and Environmental Sciences,

Faculty of Science, University of Copenhagen,

Thorvaldsensvej 40,

1871 Frederiksberg, Denmark

e-mail: myles@life.ku.dk 